\title{
Using negative and positive social feedback from a robotic agent to save energy
}

\section{Citation for published version (APA):}

Midden, C. J. H., \& Ham, J. R. C. (2009). Using negative and positive social feedback from a robotic agent to save energy. In H. Gutscher, H-J. Mosler, B. Meyer, S. Mischke, \& M. Soland (Eds.), Abstract presented at the 8th Biennial Conference on Environmental Psychology, September 6-9, 2009, Zürich (pp. 123-123). Pabst Science Publishers.

Document status and date:

Published: 01/01/2009

\section{Document Version:}

Publisher's PDF, also known as Version of Record (includes final page, issue and volume numbers)

\section{Please check the document version of this publication:}

- A submitted manuscript is the version of the article upon submission and before peer-review. There can be important differences between the submitted version and the official published version of record. People interested in the research are advised to contact the author for the final version of the publication, or visit the $\mathrm{DOI}$ to the publisher's website.

- The final author version and the galley proof are versions of the publication after peer review.

- The final published version features the final layout of the paper including the volume, issue and page numbers.

Link to publication

\section{General rights}

Copyright and moral rights for the publications made accessible in the public portal are retained by the authors and/or other copyright owners and it is a condition of accessing publications that users recognise and abide by the legal requirements associated with these rights.

- Users may download and print one copy of any publication from the public portal for the purpose of private study or research.

- You may not further distribute the material or use it for any profit-making activity or commercial gain

- You may freely distribute the URL identifying the publication in the public portal.

If the publication is distributed under the terms of Article 25fa of the Dutch Copyright Act, indicated by the "Taverne" license above, please follow below link for the End User Agreement:

www.tue.nl/taverne

Take down policy

If you believe that this document breaches copyright please contact us at:

openaccess@tue.nl

providing details and we will investigate your claim. 


\title{
Using Negative and Positive Social Feedback From a Robotic Agent to Save Energy
}

\author{
Midden, Cees J; Ham, Jaap \\ Eindhoven University of Technology, Netherlands, The
}

In this paper we explore the persuasive effects of social feedback, as provided by a robotic agent, on behavioral change. In a lab setting, two experiments were conducted in which participants had the opportunity to conserve energy while carrying out washing tasks with a simulated washing machine. The experiments tested the effect of positive and negative social feedback and compared these effects to more widely used factual feedback as provided through the simulated user-interface of a washing machine. Results of both studies indicate that social feedback has stronger persuasive effects than factual feedback (Experiment 1). Also in in comparison to a factual feedback that also included an evaluative, although non-social, component, social feedback had the strongest persuasive effects (Experiment 2). In addition, an effect of feedback valence was found, demonstrating more conservation actions following negative feedback (social or factual) as compared to positive feedback. Interestingly, negative feedback had especially strong persuasive effects when coming from a social source. These findings have several implications for theory and design of persuasive robotic agents.

c.j.h.midden@tue.nl

\section{Persuasive Agents: the Role of Agent Embodiment and Evaluative Feedback}

\author{
Vossen, Suzanna; Ham, Jaap; Midden, Cees \\ Eindhoven University of Technology, Netherlands, The
}

Social agents can serve as persuasive technology when they give feedback (FB) aimed at reducing household energy consumption. Earlier research indicated that a robotic agent is more effective in stimulating energy conservation behavior than other technical devices (Midden \& Ham, 2008). However, it was not clear why this social agent was more effective: the use of speech, agent embodiment and the feedback type were not manipulated independently. In the present study they were. We focused on the role of FB from three different sources: a computer displaying text, a talking computer and a talking social agent. Further, factual FB (FFB, the amount of energy consumed) was compared to evaluative FB (EFB, good or bad performance). Also positive FB was compared to negative FB. An experiment was conducted in which 113 participants used a virtual washing machine. They received interactive FB (either factual or evaluative) about their energy consumption from one of three sources. This FB could be positive or negative, depending on the energy consumption. We measured the change in energy consumption after FB. No main effect of feedback source was found, but the interaction with feedback valence was significant: negative FB from the social agent resulted in a larger decrease in energy consumption than negative FB from the other sources. Further, EFB was more effective than FFB, especially in case of negative feedback. Overall, negative FB resulted in a larger decrease than positive FB.

s.h.vossen@tue.nl 